\title{
Weight-of-evidence on environmental impact assessment of metal contaminated sediments in the São Francisco River (Três Marias - Minas Gerais - Brazil) - a case study
}

\author{
Almeida, DF ${ }^{a *}$, Martins, $A H^{b *}$ and Tundisi, JG. ${ }^{c *}$ \\ aVotorantim Metais Zinco S.A., Rod. BR 040, Km 284, Três Marias, MG, Brazil

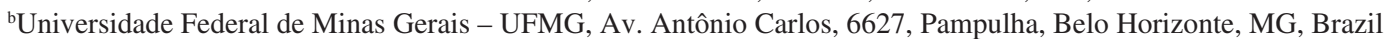 \\ 'Instituto Internacional de Ecologia e Gerenciamento Ambiental - IIEGA, \\ Rua Bento Carlos, 750, Centro, São Carlos, SP, Brazil \\ *e-mail: debora.almeida@vmetais.com.br; ahmartin@demet.ufmg.br; tundisi@iie.com.br \\ Received August 26, 2010 - Accepted February 8, 2011 - Distributed November 30, 2011
}

(With 8 figures)

\begin{abstract}
The weight-of-evidence - WOE approach was used to assess the environmental impact of sediments contaminated by metals in the São Francisco river and one of its tributaries, Consciência creek, both affected by anthropic activities, in the region of Três Marias (Minas Gerais/Brazil). The assessment provided support to a risk management decision. The WOE was based on bulk metal analysis, AVS-SEM assays, elutriate tests, ecotoxicity assays, benthic community assessment and a comparison for the reference area. Brazilian legislation and other available literature were used as criteria to evaluate the lines of evidence. All samples, except for the reference area, presented some contamination. However, geochemical testing for bioavailability studies showed that toxicity is unlikely as suggested by the chemical results. Ecotoxicity and benthic structure studies provided further information to support decision making. Metal acid volatile sulfide formation mechanisms were identified, which can eventually attenuate metal toxicity observed. The removal of active sources of contamination (for example, from tailings dumps) associated with Monitoring Natural Recovery could be sufficient to eventually lessen the risk of the biota in São Francisco river sediments.
\end{abstract}

Keywords: weight of evidence, contamination, sediments, São Francisco river.

\section{Balanço das evidências na avaliação do impacto ambiental por sedimentos contaminados por metais no Rio São Francisco (Três marias - Minas Gerais - Brasil) - um estudo de caso}

\section{Resumo}

Esse artigo teve como objetivo avaliar o impacto da contaminação por metais dos sedimentos de corrente do Rio São Francisco e de um de seus tributários, Córrego Consciência, na região de Três Marias (Minas Gerais/Brasil), ambos impactados por atividades antrópicas, a partir da metodologia de Balanço das Evidências - BDE, e, dessa forma, prover embasamento para uma decisão de gerenciamento de risco. Para o BDE se utilizou resultados de: concentração de metal nos sedimentos, ensaios de SVA-MES, ensaios de elutriação, ensaios de ecotoxicidade, estudo da comunidade bentônica. Legislação nacional e outras literaturas disponíveis foram utilizadas como critério de avaliação das linhas de evidências. Todas as amostras, exceto pela área de referência, apresentou alguma contaminação. Entretanto, ensaios geoquímicos para estudo da biodisponibilidade demonstraram que a toxicidade não é provável como sugeriram os resultados químicos. Estudos de ecotoxicidade e de estrutura da comunidade bentônica forneceram informações complementares importantes para embasar a tomada de decisão quanto ao gerenciamento ambiental dos sedimentos. Mecanismos de formação de metais volatilizáveis por acidificação foram identificados, podendo atenuar a toxicidade eventualmente verificada. A remoção de fontes ativas de contaminação associada ao Monitoramento da Recuperação Natural pode, portanto, ser suficiente para diminuir o risco à biota, eventualmente identificado nos sedimentos do Rio São Francisco.

Palavras-chave: balanço das evidências, contaminação, sedimentos, Rio São Francisco. 


\section{Introduction}

The São Francisco river starts in Minas Gerais State/ Brazil and crosses four Brazilian States before reaching the Atlantic Ocean. In the city of Três Marias/Minas Gerais State, there have been many activities along this river, such as: electricity generation, zinc metallurgy, sewage discharge and agriculture. Contamination from metals in the water and sediments has been extensively studied by universities, industries, the Government, communities and NGOs, but metal bioavailability and its effect on the aquatic organisms are not commonly studied in this region (Lundhamer, 1991; Oliveira, 2007; Saraiva, 2007; IIEGA, 2006, 2007; Golder, 2006; Mozeto et al., 2005, 2007).

Environmental impacts cannot be assessed exclusively by chemical analyses of contamination sources. They can be assessed to a limited extent by toxicity tests, which try to reproduce the response of standardized organisms to contaminated materials in the laboratory. However, laboratory tests are simplistic and do not take into account biological, chemical and physical differences between the laboratory and the field, neither the adaptation of in situ organisms to the real environment. Determination of the status of resident exposed organisms (e.g. measurements of the benthic community structure) provides more realistic measures of environmental impacts. However, field populations which typically show natural variability and cause for any changes can be difficult to establish. Therefore, when assessing an environmental impact, as much information as possible must be investigated and interpreted together to support an efficient decision on environmental risk management. This information, also called lines of evidences - LOE, should be investigated and evaluated according to its relevance in a weight of evidence approach - WOE (Chapman and Anderson, 2005; Chapman et al., 2002; Chapman 2007; McPherson et al., 2008).

The weight-of-evidence WOE approach was used to assess the metal contamination impact of the São Francisco river bed sediments and one of its tributaries, Consciência creek, in the region of Três Marias (Minas Gerais/Brazil). The following LOEs were studied: bulk metal analysis, AVS-SEM assays, elutriate tests, ecotoxicity assays and benthic community assessment. This is also part of a doctorate thesis (Almeida, 2010) which used the WOE determination to indicate measures of environmental risk management.

\section{Materials and Methods}

\subsection{Sampling}

Studies on sediments were developed in the bed of both the São Francisco river and the tributary Consciência creek, $\mathrm{i}$, both located in the city of Três Marias (Minas Gerais/ Brazil). Sediments were sampled in the locations (Figure 1).

Sediment samplings took place on the following dates: a) benthic community, December 2008 , b) bulk metal analysis and AVS-SEM assays, October 2008, c) elutriate tests, September 2008, d) ecotoxicity assays, May 2008.

Sediments of the benthic community assessment were sampled using a Petersen $5 \mathrm{~L}$ dredge (open dredge reaches an area of approximately $365 \mathrm{~cm}^{2}$ ). Five samples were taken in P1, P2, P3, P4 and P5 and three samples in P7 and P6. Sediments were preserved in formalin (8\%) for transportation. In the laboratory, sediments were washed in a $0.25 \mathrm{~mm}$ sieve and then preserved in alcohol (70\%). Sampling and benthos were identified in partnership with the Instituto Intenacional de Ecologia e Gestão Ambiental (IIEGA) located in São Carlos (São Paulo state).

Sampling of sediments for bulk metal analysis, AVSSEM assays, elutriate tests and ecotoxicity assays were conducted in partnership with Golder Associates Brasil, located in Belo Horizonte (Minas Gerais), using a 4.5 L dredge VanVeen (open dredge reaches an area of approximately $300 \mathrm{~cm}^{2}$ ). Approximately $20 \mathrm{~kg}$ of sediments were sampled in each location. The material was homogenized, divided into smaller samples and stored in refrigeration.

Duplicate samples were collected in order to ensure adequate quality control (QA/QC) for sampling and analysis

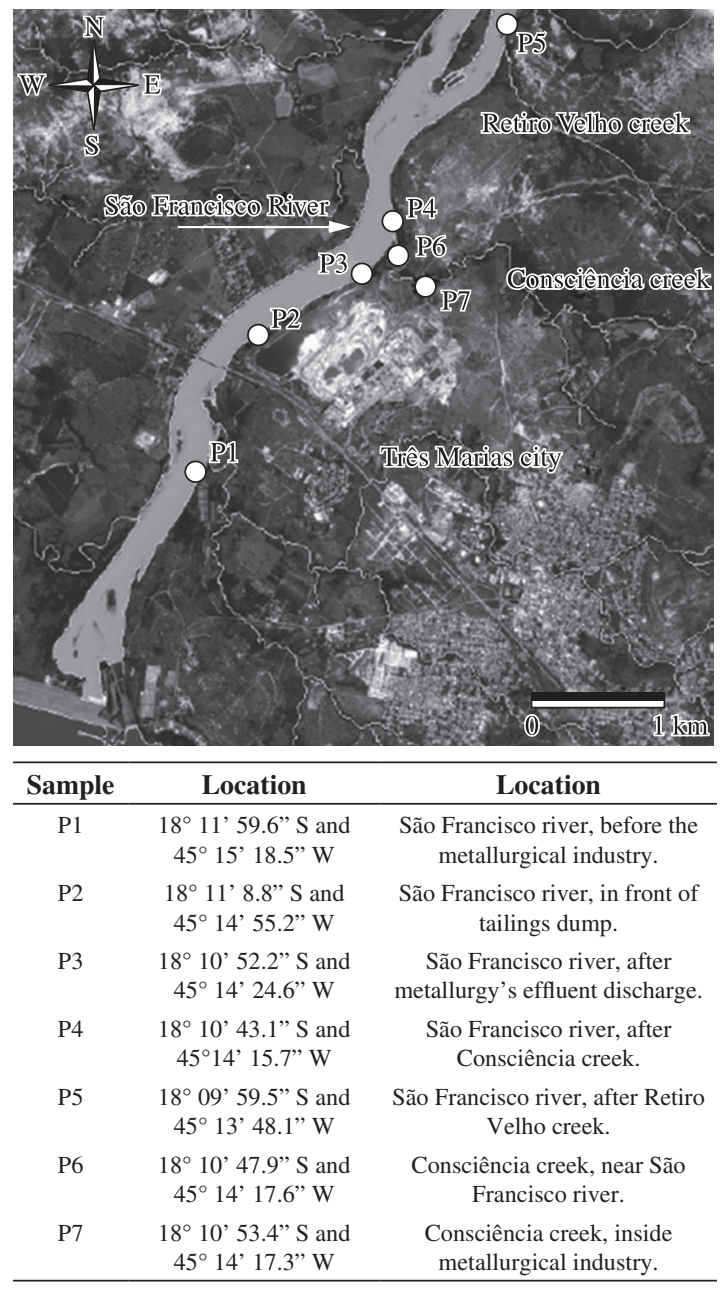

Figure 1. Location of sediment samples. 
methods. Samples P3 and P4 were homogenized and divided into two samples (duplicates) as quality control for chemical analysis and ecotoxicity assays. P2 was sampled twice, i.e. technically the two are not the same sample, but they were called P2 and P2 duplicate and were used as quality control for the sampling procedure. Duplicate results were analyzed according to the methodology proposed by EPA (1995) using the index RPD (Relative Percentage Difference), which should be below $20 \%$ so the QA/QC is considered adequate. Sediment samples were not grounded, because the aim was to assess the bioavailability rather than total metal content, therefore a difference between duplicates may occur above $20 \%$. A higher difference is expected between P2 and P2 duplicate because they are not the same sample.

Elutriate tests were conducted by Votorantim Metais (Três Marias/Minas Gerais) and Golder Associates Brasil. Bulk metal analysis and AVS-SEM assays were conducted in partnership with SGS-Geosol, located in Belo Horizonte (Minas Gerais). Ecotoxicity tests were conducted in partnership with Labtox, located in Rio de Janeiro (Rio de Janeiro state).

\subsection{Bulk metal analysis}

Samples were prepared according to the Standard Method 3050B (APHA, 2005; EPA, 1996a), which consisted of a multi-acid digestion $\left(\mathrm{HNO}_{3}, \mathrm{HCl}\right.$ and $\left.\mathrm{H}_{2} \mathrm{O}_{2}\right)$. The metals zinc $(\mathrm{Zn})$, cadmium $(\mathrm{Cd})$, copper $(\mathrm{Cu})$, lead $(\mathrm{Pb})$ and nickel (Ni) were quantified by ICP-OES (inductively coupled plasma optical emission spectrometer), model Optima 5300DV/Perking Elmer, according to the Standard Methods 3030 and 3120 (APHA, 2005). Quality control consisted of standard sample analyses. Results were accepted when recovery rates from standard samples analyses ranged between 80 and $100 \%$.

Contamination or bulk metals were compared to Brazilian legislation CONAMA (2004) which adopted the guidelines from the Canadian Council of Ministers of the Environment - CCME: Level 1 corresponds to TEL (threshold effect level), Level 2 corresponds to PEL (probable effect level) (CCME, 1999).

\subsection{AVS-SEM assays}

Samples were submitted to AVS-SEM assays, according to procedures established in EPA (1991). Sediments ( $2 \mathrm{~g}$ ) were weighed and placed into reaction flasks with $100 \mathrm{~mL}$ of deionized water. They were then agitated and underwent a $\mathrm{N}_{2}$ flow. Then, $20 \mathrm{~mL}$ of HCL (6M) was added using a syringe. The volatilized sulfides $\left(\mathrm{H}_{2} \mathrm{~S}\right)$ were purged from reaction flasks by $\mathrm{N}_{2}$ and trapped into receptor flasks by $\mathrm{NaOH}$ solution. The solution which corresponds to SEM was filtered in a $0.45 \mathrm{~mm}$ membrane and was submitted to determination of metals $(\mathrm{Cu}, \mathrm{Cd}, \mathrm{Pb}$, $\mathrm{Ni}, \mathrm{Zn}$ ) according to Standard Methods 3030 and 3120. For sulfide determination, the colorimetric method with methylene blue was used: 4500S2-D. Total organic carbon was analyzed in a Shimadzu's TOC.
Bioavailability results (SEM-AVS) were compared to the bounds described in EPA (2005). These bounds were derived from acute toxicity experiments conducted by DiToro $(1990,1991,2000)$, by compiling toxicity data from literature and establishing two uncertainty bounds that correspond to the concentration range where it is $90 \%$ certain that sediments may either be toxic or non-toxic (EPA, 2005).

\subsection{Elutriate tests}

Elutriate tests were conducted according to the methodology described in Plumb (1981). Originally, the procedure was proposed to assess the potential impact of dredging activities to the water. In this work, elutriate tests were used to estimate the stability of metals in sediments subjected to re-suspension or oxygenation.

Samples were mixed with deionized water at a ratio of 1:4 ( $8 \mathrm{~L}$ of water and $2 \mathrm{~L}$ of sediments) and were then mixed for 30 minutes at 500 RPM. The parameters Eh, $\mathrm{pH}$, conductivity and dissolved oxygen were measured at three different moments: at the beginning of the experiment, after 30 minutes of mixing and after 60 minutes of resting. Each sample underwent 3 identical experiments.

The elutriate was filtered in filter paper $(1 \mathrm{~mm})$ to separate the colloids from the solution, and then divided into 2 aliquots. One aliquot was filtered in nylon membrane $(0.45 \mathrm{~mm})$. All solutions were analyzed in ICP-OES (Optima 5300DV/PerkingElmer) according to the Standard Methods 30302 3120B (APHA, 2005).

Elutriate test results were compared to Brazilian legislation (CONAMA, 2005), considering protection to aquatic life (Class 2). However, a comparison with quality criteria is overly conservative, because site dilution is not considered. Therefore, an elutriate test result which is below the established criteria will indicate that adverse impacts are not expected to occur. On the other hand, an elutriate test result exceeding criteria would not necessarily imply in an adverse impact (Plumb, 1991).

\subsection{Ecotoxicity assays}

Ecotoxicity tests were conducted in sediments and pore (interstitial) water samples. The pore water samples were handled in order to either isolate or modify toxicity of certain substances, as an attempt to identify the influence of metals and sulfide gas $\left(\mathrm{H}_{2} \mathrm{~S}\right)$ in the eventually verified toxicity, since sulfide from AVS formation may be toxic (Chapman and Wang, 1999).

The sediments were maintained below $10{ }^{\circ} \mathrm{C}$. The pore water was extracted by a refrigerated centrifuge model Beckman J2 21M at 7500 RPM for 15 minutes according to NBR 15469 (ABNT, 2007b). Aliquots of extracted liquid were treated with: 1 ) addition of $30 \mathrm{mg} / \mathrm{L}$ of EDTA (ethylenediaminetetraacetic acid) according to EPA(1996b), 2) acidification, $\mathrm{pH}$ correction and aeration with nitrogen to eliminate $\mathrm{H}_{2} \mathrm{~S}$. Both treated and non-treated pore waters were used to prepare the following solution-tests: $6.25 \%$, $12.5 \%, 25 \%, 50 \%$ and $100 \%$. Assays were made in replicate of 4 (acute in pore water), 5 (acute in sediments) and 10 
(chronic in pore water). The amount of material needed for each assay was $200 \mathrm{~kg}$ (sediments), $15 \mathrm{~mL}$ (acute in pore water) and $10 \mathrm{~mL}$ (chronic in pore water).

Ecotoxicity assays were conducted in sediments with the amphipod Hyalella azteca, according to NBR 15470 (ABNT, 2007a) and in pore water (both treated and nontreated) for the crustaceans Daphnia similis (acute) and Ceriodaphnia dubia (chronic), according to NBR 12713 (ABNT, 2004) and NBR 13373 (ABNT, 2005), respectively.

The organisms used may not be naturally found in Brazilian ecosystems, but were standardized by the Technical Standard Brazilian Association (Associação Brasileira de Normas Técnicas - ABNT), and therefore are commonly used in ecotoxicity assays in Brazil. It is better practice to develop standard methods with local species, i.e. from the São Francisco river adapted to the local environment. However, there has to be a previous and extensive study on existing species and their sensibility to contaminations to then develop and standardize procedures for toxicity assays with local species. There are some studies on Brazilian native species such as Chironomus xanthus and Branchiura sowerbyi (Almeida, 2007). However, no studies on native species in the São Francisco watershed were identified and there was no standardization by ABNT. Meanwhile, existing procedures are sufficient as LOE. However, interpretation should take into consideration that results may not be representative of reality.

Ecotoxicity results were compared to reference sample (P1) and control assays. Both acute assays in sediments and chronic assays in pore water were evaluated according to the significant difference to control assay, using the Steel's Many-One Rank test from the statistic software Toxstat 3.3 (Gulley et al., 1991). Acute toxicity results from pore water assays were treated according to the methodology Trimmed Spearman Karber (Hamilton et al., 1977) to derive toxicity concentrations EC50.

Assays conducted in sediments with Hyalella azteca are conservative because sediments are not preferable habitats for such organisms. Absence of toxicity is strong evidence of no adverse effect to biota, while presence of toxicity in laboratory does not necessarily mean an in situ adverse effect (Wang et al., 2004).

Concerning tests in pore water, although they may provide important information on sediment pollution, they may either overestimate or underestimate their toxicity, because of some limitations: pore water may not be the only exposure route, pore water tests lack chemical or biological realism, their sensitivity concerning other tests may be meaningless due to handling in the laboratory, many sediment and surface dwelling organisms are not directly influenced by pore water (Chapman et al., 2002).

\subsection{Benthic community}

Benthic community structure was evaluated according to the Biological Monitoring Working Party - BMWP modified by Junqueira et al. (2000), used in Das Velhas river, a direct tributary stream of the São Francisco river. Some families identified in sediment samples were not described in by Junqueira et al. (2000), therefore other references were used: Castro (2006), Roldan (2003) and Alba-Tercedor and Sanchez-Ortega (1988). The BMWP is a qualitative procedure that is based on the principle that different benthic organisms have different tolerance to pollutants, mainly organic. BMWP score equals the sum of the tolerance scores of all macroinvertabrate families in the sample, regardless of the abundance. A higher BMWP score is considered to reflect a better environmental quality.

\subsection{Criteria to evaluate lines of evidences}

The LOEs were evaluated according to the criteria described in Table 1, which were based on Brazilian legislation, international quality criteria, available literature and, when pertinent, comparison with reference sample P1 and control samples.

\subsubsection{Contamination}

Samples that presented all parameters below Level 1 were unlikely to cause adverse affects to biota. On the other hand, if any parameter is above Level 2, then an adverse effect was likely to occur. Intermediate cases are uncertain and need more studies. This criterion is the same as legislation criteria (CONAMA, 2004; CCME, 1999).

\subsubsection{Bioavailability}

When there was no excess SEM or organic carbon normalization resulted in below $130 \mathrm{~mm} / \mathrm{g}$ dry weight, then an adverse effect was evaluated as improbable. When there was positive excess MES and organic carbon normalization resulted in above $3000 \mathrm{~mm} / \mathrm{g}$ dry weight, then an adverse effect was evaluated as probable. Values between 130 and $3000 \mathrm{~mm} / \mathrm{g}$ for organic carbon normalized excess SEM were of uncertain toxicity. These bounds were derived from Ditoro et al. (1990, 1991, 2000).

\subsubsection{Stability}

Elutriate results better than established criteria, according to CONAMA (2005), indicated improbable adverse effect; results exceeding criteria, for any parameter, indicated uncertain adverse effects because of the overly conservative nature described in methods. This method is not able to detect adverse effects for biota, but provides insights of solubilization potential.

\subsubsection{Ecotoxicity}

Sediments: No significant difference in sediment ecotoxicity assays meant improbable adverse effects; a significant difference meant probable adverse effects, despite the conservative nature of the test. Pore water acute toxicity: Provided limitations described in methods, absence of toxicity (EC50 > 100\%) indicated improbable adverse effect to biota; EC50 $\leq 100 \%$ (toxic) indicated probable adverse effect. Pore water chronic toxicity: As reference sample (P1) presented some toxicity, results from other samples were considered: "uncertain adverse effect" when they were similar to reference sample; "probable adverse 
Table 1. Criteria to evaluate evidence.

\begin{tabular}{|c|c|c|c|}
\hline LOE & & & \\
\hline Contamination ${ }^{1}$ & $\mathrm{~m} \leq$ Level 1 & Level $1<\mathrm{m} \leq$ Level 2 & $m>$ Level 2 \\
\hline Bioavailability $^{2}$ & $(\Sigma \mathrm{SEM}-\mathrm{AVS}) / \mathrm{f}_{\mathrm{TOC}} \leq 130$ & $130<(\Sigma$ SEM-AVS $) / f_{\text {TOC }}>3000$ & $(\Sigma \mathrm{SEM}-\mathrm{AVS}) / \mathrm{f}_{\mathrm{TOC}} \geq 3000$ \\
\hline Stability $^{3}$ & $\mathrm{Me} \leq \mathrm{CONAMA}$ & $\mathrm{Me}>$ CONAMA & - \\
\hline $\begin{array}{l}\text { Sediment acute } \\
\text { toxicity }^{4}\end{array}$ & No significant difference & & Significant difference \\
\hline $\begin{array}{l}\text { Pore water acute } \\
\text { toxicity }\end{array}$ & No acute toxicity & - & Acute toxicity \\
\hline $\begin{array}{l}\text { Pore water chronic } \\
\text { toxicity }^{6}\end{array}$ & No chronic toxicity & $\mathrm{ChV} \geq \mathrm{ChV}_{\mathrm{P} 1}$ & $\begin{array}{l}\text { Chronic toxicity and } \mathrm{ChV} \\
\qquad<\mathrm{ChV}_{\mathrm{P} 1}\end{array}$ \\
\hline $\begin{array}{l}\text { Toxicity } \\
\text { identification }^{7}\end{array}$ & Not identified & - & Identified \\
\hline \multirow[t]{2}{*}{ Benthic community $^{8}$} & $\mathrm{BMWP} \geq 64$ & $17 \leq \mathrm{BMWP} \leq 63$ & $\mathrm{BMWP} \leq 16$ \\
\hline & Improbable adverse effect & Adverse effect uncertain & Probable adverse effect \\
\hline
\end{tabular}

References: 1) CONAMA (2004); 2) EPA (2005); 3) CONAMA (2005), 4-6) Presence/absence of toxicity and comparison with reference sample P1; 7) Comparison between assays realized before and after handling with EDTA (to verify influence of metals on toxicity); 8) Junqueira et al. (2000). Definitions/acronyms: 1) m = bulk metal concentration; 2) SSEM = molar sum of simultaneously extracted metals ( $\mathrm{mmol} / \mathrm{g})$; AVS: acid volatile sulfides $(\mathrm{mmol} / \mathrm{g}) ; \mathrm{f}_{\text {тос }}=$ fraction of total organic carbon; 3) $\mathrm{Me}_{\text {diss }}=$ elutriate metal concentration; 4) $\mathrm{Me}_{\mathrm{PSF} 01}=$ elutriate metal concentration in reference sample P1; 5) EC50= half maximal effective concentration, or concentration that causes response from $50 \%$ of population; 6) $\mathrm{ChV}=$ chronic value; 8) $\mathrm{BMWP}=$ Biological Monitoring Working Party.

effect" when toxicity was higher than P1. Handling: Ecotoxicity results after handling (treatment with EDTA and $\mathrm{N}_{2}$ ) were evaluated according to the metal influence on the toxicity observed. When toxicity was probably related to metal contamination, i.e. toxicity decreased with EDTA addition), it meant probable adverse effects (of metals). Otherwise it meant improbable adverse effect.

\subsubsection{Benthic community}

BMWP scores that resulted in excellent and good quality criteria (Junqueira et al., 2000) were considered of improbable adverse effect; BMWP scores that resulted in very bad quality criteria were considered of probable adverse effect; intermediate BMWP scores were considered of an uncertain effect.

To support a systemic and consistent assessment on a sediment contamination impact, provided that results may contradict because of varied intrinsic uncertainties, the LOEs were weighed according to their relevance. Critical to the WOE process are three factors: the weight assigned to each measure; the magnitude of response observed in each measure; and concurrence among multiple measures (Chapman, 2007).

In this work, weight criteria reflected the fact that studies on bioavailability are more representative of environmental quality than total metal concentration; ecotoxicity tests are closer to representing the effect of contaminants than any chemical analyses; and that the most important LOE is associated with benthic community structures which reflect in situ contamination effects.

\section{Results}

\subsection{Bulk metals}

The results for bulk metals are plotted in Figure 2a,b. To visualize it better, the results were normalized to CONAMA (2004) Levels 1 and 2. Standard sample recovery rates varied between $80 \%$ and $100 \%$, assuring quality control.

Metal concentrations in the reference sample (P1) were below Level 2 and 1 (CONAMA, 2004), i.e. the sample was not contaminated. On the other hand, the samples P2, P4, $\mathrm{P} 5, \mathrm{P} 7$ and $\mathrm{P} 6$ resulted in zinc and cadmium concentrations above Level 2. The samples P2, P7 and P6 also contained lead above Level 2 (CONAMA, 2004). The sample P3 was above Level 1, but not above Level 2.

The RPDs (Relative Percentage Difference) analyses are presented in Table 2. The duplicates of P3 and P4 varied little $(<20 \%)$ for most metals if compared to the original analysis, except zinc ( $\mathrm{Zn})$ in P3 $(53 \%)$ and nickel (Ni) in P4 (40\%). Duplicate for P2, however, varied more than $20 \%$ for most metals (up to $126 \%$ ) because it was another sample in the same location and not the same sample divided into two, reflecting variability between samplings.

\subsection{SEM-AVS assays}

The results for SEM-AVS are presented in Table 3. The reference sample $\mathrm{P} 1$ presented negative results. Therefore, toxicity is not expected. The other samples presented positive results, which were TOC normalized and presented in Figure 3, following the guidelines proposed by Ditoro et al. (1990, 1991, 2000). The excess SEM of the São Francisco river sediment samples consists essentially 
Bulk metal concentration normalized by level 2 (a) (CONAMA, 2004)

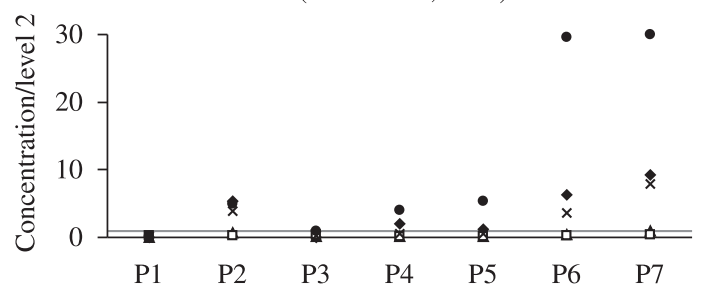

- $\mathrm{Cd} \quad \Delta \mathrm{Cu} \quad \square \mathrm{Ni} \quad \times \mathrm{Pb} \quad \cdot \mathrm{Zn}$
Bulk metal concentration normalized by level 1 (b) (CONAMA, 2004)

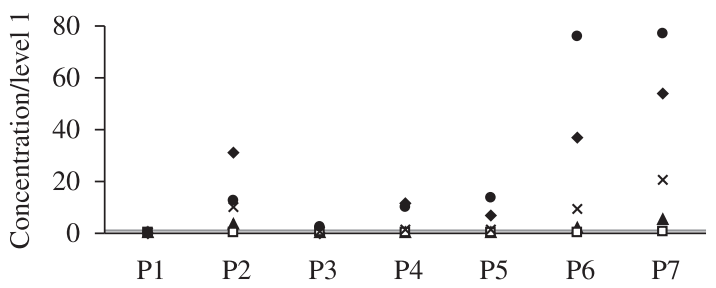

Figure 2. a) Level 2 normalized bulk metal concentration ( $\mathrm{Zn}, \mathrm{Cd}, \mathrm{Pb}, \mathrm{Cu}$ and $\mathrm{Ni}$ ); b) Level 1 normalized bulk metal concentration ( $\mathrm{Zn}, \mathrm{Cd}, \mathrm{Pb}, \mathrm{Cu}$ and $\mathrm{Ni})$.

Table 3. Concentrations of simultaneously extracted metals (SEM) and acid volatile sulfides (AVS).

\begin{tabular}{|c|c|c|c|c|c|c|c|c|}
\hline \multirow{3}{*}{ Samples } & \multicolumn{5}{|c|}{ SEM } & \multirow{2}{*}{$\Sigma S E M$} & \multirow{2}{*}{$A V S$} & \multirow{2}{*}{$\begin{array}{c}\Sigma S E M- \\
A V S\end{array}$} \\
\hline & $\mathrm{Cu}$ & $P b$ & $C d$ & $Z n$ & $N i$ & & & \\
\hline & \multicolumn{8}{|c|}{$\mu \mathrm{mol} / \mathrm{g}$} \\
\hline DL & 0.07 & 0.06 & 0.04 & 0.07 & 0.07 & - & - & - \\
\hline $\mathrm{P} 1$ & 0.28 & 0.09 & $<\mathrm{DL}$ & 0.39 & 0.06 & 0.86 & 2.31 & -1.45 \\
\hline $\mathrm{P} 2$ & 0.28 & 0.12 & $<\mathrm{DL}$ & 13.93 & 0.12 & 14.49 & 6.24 & 8.25 \\
\hline P2 (duplicata) & 0.39 & 0.14 & $<\mathrm{DL}$ & 16.17 & 0.08 & 16.81 & 4.37 & 12.45 \\
\hline P3 & 0.20 & 0.14 & $<\mathrm{DL}$ & 7.46 & $<\mathrm{DL}$ & 7.92 & 0.62 & 7.30 \\
\hline P3 (duplicata) & 0.16 & 0.12 & $<\mathrm{DL}$ & 1.92 & $<\mathrm{DL}$ & 2.31 & 0.94 & 1.37 \\
\hline P4 & 0.15 & 0.21 & 0.05 & 18.82 & 0.07 & 19.30 & 10.92 & 8.38 \\
\hline P4 (duplicata) & 0.13 & 0.19 & 0.05 & 16.54 & $<\mathrm{DL}$ & 16.98 & 10.61 & 6.37 \\
\hline P5 & 0.22 & 0.30 & $<\mathrm{DL}$ & 26.61 & $<\mathrm{DL}$ & 27.23 & 7.80 & 19.43 \\
\hline P7 & 1.34 & 2.45 & 0.18 & 126.23 & $<\mathrm{DL}$ & 130.26 & 2.18 & 128.08 \\
\hline P6 & 0.56 & 1.12 & 0.14 & 115.25 & 0.08 & 117.14 & 9.36 & 107.78 \\
\hline
\end{tabular}

DL: detection limits. - não existe limite de detecção para os parâmetros SEM ou AVS

Table 2. RPD analysis for duplicate samples (total metal concentration).

\begin{tabular}{lccccc}
\hline \multirow{2}{*}{ Samples } & $\mathbf{C d}$ & $\mathbf{C u}$ & $\mathbf{N i}$ & $\mathbf{P b}$ & $\mathbf{Z n}$ \\
\cline { 2 - 6 } & \multicolumn{5}{c}{$\mathbf{~ m g / k g}$} \\
\hline P2 & 18.7 & 126 & 8 & 353 & 1572 \\
P2 (duplicate) & 5.9 & 28.8 & 8 & NA & 1199 \\
RDP & $\mathbf{1 0 4 \%}$ & $\mathbf{1 2 6 \%}$ & $\mathbf{0 \%}$ & $\mathbf{N A}$ & $\mathbf{2 7 \%}$ \\
P3 & $<3$ & 17.4 & 15 & 22 & 315 \\
P3 (duplicate) & $<3$ & 15.8 & 15 & 19 & 183 \\
RDP & $\mathbf{0 \%}$ & $\mathbf{1 0 \%}$ & $\mathbf{0 \%}$ & $\mathbf{1 5 \%}$ & $\mathbf{5 3 \%}$ \\
P4 & 7 & 15.7 & 6 & 48 & 1255 \\
P4 (duplicate) & 6.2 & 13.7 & 4 & 43 & 1156 \\
RDP & $\mathbf{1 2 \%}$ & $\mathbf{1 4 \%}$ & $\mathbf{4 0 \%}$ & $\mathbf{1 1 \%}$ & $\mathbf{8 \%}$ \\
\hline
\end{tabular}

of zinc $(\mathrm{Zn})$ and nickel $(\mathrm{Ni})$, more soluble than lead $(\mathrm{Pb})$, copper $(\mathrm{Cu})$ and cadmium $(\mathrm{Cd})$ which apparently are in AVS form and consequently unavailable for biota. Sample P7, in Consciência creek, behaves differently. The present AVS is sufficient to link copper $(\mathrm{Cu})$ and part of lead $(\mathrm{Pb})$.
The excess SEM of sample P7 consists of lead $(\mathrm{Pb})$, cadmium (Cd), zinc ( $\mathrm{Zn})$ and nickel $(\mathrm{Ni})$.

The RPD (Relative Percentage Difference) analyses are presented in Table 4 . The duplicate of $\mathrm{P} 4$ varied little $(<20 \%)$ for most metals if compared to its original analysis. Duplicate of P2 varied up to $41 \%$, less than in bulk metal analysis using the 3050B method. P3, on the other hand, varied $118 \%$ for metal zinc ( $\mathrm{Zn})$ and the reason was not determined. Some of it could be attributed to the fact that the sample was not ground, but if it had been, this would also reflect on the bulk metal analysis. More probable is the uncertainty intrinsic to the SEM-AVS method.

\subsection{Geochemical stability (elutriate experiments)}

The results of metal analysis (total and dissolved) in the elutriate are presented in Table 5 and were compared to CONAMA (2005) and reference sample (P1). P4 and P6 were not sampled and therefore not analyzed. The grey colored cells indicate values that are above legislation (CONAMA, 2005).

All elutriates presented some metal concentration above legislation (CONAMA, 2005), including reference sample (P1) that exceeded in lead (Pb), zinc ( $\mathrm{Zn})$ and nickel (Ni), when the total fraction was analyzed. This is expected 


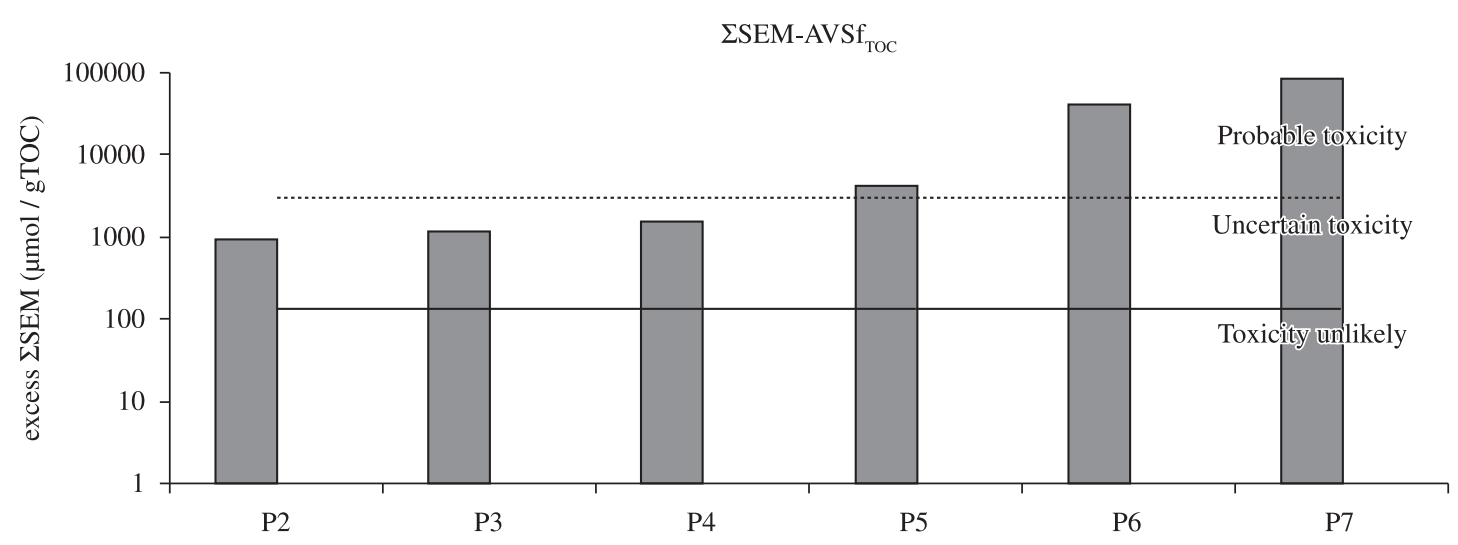

Figure 3. Total organic carbon normalized excess SSEM.

Table 4. RPD analysis for duplicate samples (AVS and SEM).

\begin{tabular}{lccccccc}
\hline \multirow{2}{*}{ Samples } & $\mathbf{C d}$ & $\mathbf{C u}$ & $\mathbf{N i}$ & $\mathbf{P b}$ & $\mathbf{Z n}$ & SMES & SVA \\
\cline { 2 - 8 } & & & $\mu \mathbf{m o l} / \mathbf{g}$ & & & \\
\hline P2 & $<0.04$ & 0.28 & 0.12 & 0.12 & 13.93 & 14.48 & 6.24 \\
P2 (duplicate) & $<0.04$ & 0.39 & 0.08 & 0.14 & 16.17 & 16.81 & 4.37 \\
RPD & $\mathbf{3 \%}$ & $\mathbf{3 2 \%}$ & $\mathbf{4 1 \%}$ & $\mathbf{1 7 \%}$ & $\mathbf{1 5 \%}$ & - & $\mathbf{3 5 \%}$ \\
P3 & $<0.04$ & 0.20 & $<0.07$ & 0.14 & 7.46 & 7.91 & 0.62 \\
P3 (duplicate) & $<0.04$ & 0.16 & $<0.07$ & 0.12 & 1.92 & 2.31 & 0.94 \\
RPD & $\mathbf{1 3 \%}$ & $\mathbf{2 2 \%}$ & $\mathbf{2 \%}$ & $\mathbf{2 1 \%}$ & $\mathbf{1 1 8 \%}$ & - & $\mathbf{4 0 \%}$ \\
P4 & 0.05 & 0.15 & 0.07 & 0.21 & 18.82 & 19.30 & 10.92 \\
P4 (duplicate) & 0.05 & 0.13 & $<0.07$ & 0.19 & 16.54 & 16.97 & 10.61 \\
RPD & $\mathbf{1 \%}$ & $\mathbf{1 6 \%}$ & $\mathbf{8 \%}$ & $\mathbf{7 \%}$ & $\mathbf{1 3 \%}$ & - & $\mathbf{3 \%}$ \\
\hline
\end{tabular}

Table 5. Concentration of metals in elutriate.

\begin{tabular}{|c|c|c|c|c|c|c|c|c|c|c|}
\hline \multirow{4}{*}{ Unit } & \multicolumn{10}{|c|}{ Parameters } \\
\hline & \multicolumn{5}{|c|}{ Total } & \multicolumn{5}{|c|}{ Dissolved } \\
\hline & Cd & $\mathbf{C u}$ & $\mathbf{P b}$ & Zn & $\mathrm{Ni}$ & Cd & $\mathrm{Cu}$ & $\mathbf{P b}$ & Zn & $\mathbf{N i}$ \\
\hline & \multicolumn{5}{|c|}{$\mathrm{mg} / \mathrm{L}$} & \multicolumn{5}{|c|}{$\mathrm{mg} / \mathrm{L}$} \\
\hline DL & 0.001 & 0.009 & 0.01 & 0.01 & 0.02 & 0.001 & 0.009 & 0.01 & 0.01 & 0.02 \\
\hline Legislation & 0.001 & - & 0.01 & 0.18 & 0.025 & - & 0.009 & - & - & - \\
\hline P1 & $<0.001$ & 0.59 & 0.74 & 0.36 & 0.18 & $<0.001$ & $<0.009$ & 0.05 & 0.19 & $<0.02$ \\
\hline $\mathbf{P 2}$ & 0.027 & 0.04 & 0.13 & 7.23 & $<0.02$ & $<0.001$ & $<0.009$ & 0.02 & 0.18 & $<0.02$ \\
\hline P3 & $<0.001$ & $<0.009$ & $<0.01$ & 0.22 & $<0.02$ & $<0.001$ & $<0.009$ & $<0.01$ & $<0.01$ & $<0.02$ \\
\hline P5 & 0.142 & 1.42 & 7.43 & 42.8 & 0.09 & $<0.001$ & $<0.009$ & 0.03 & 0.20 & $<0.02$ \\
\hline P7 & 0.012 & 0.08 & 0.80 & 50.9 & 0.04 & $<0.001$ & $<0.009$ & 0.21 & 48.4 & $<0.02$ \\
\hline
\end{tabular}

DL: detection limit.

since, due to re-suspension procedure, suspended particles were analyzed together with the soluble compounds, which reflects sediment quality not water. This is clear when dissolved fractions are analyzed.

When it comes to geochemical stability of sediments, it is important to analyze the soluble fraction. Although high total metal concentrations were observed, almost all samples profiles were very similar to the reference sample (P1), except for sample P7, in Consciência creek, which presented high concentrations of dissolved zinc ( $\mathrm{Zn}$ ) and lead $(\mathrm{Pb})$ in the elutriate (Figure 4).

\subsection{Ecotoxicity}

\subsubsection{Ecotoxicity in sediments}

The results of sediments toxicity are presented in Figure 5. P4 was not sampled for biological assays. According to the results, samples P2 (original and duplicate, in front of the old tailings dump), PCS 10 and P6 (Consciência 
creek) presented a significant difference compared to the control sample. P5 presented no mortality, although results from geochemical analysis indicated contamination.

\subsubsection{Ecotoxicity of non-treated pore water}

Results of acute (Daphnia similis) and chronic (Ceriodaphnia dubia) toxicity of non-treated pore water are presented in Figure 6. It was not possible to extract pore water from samples P2 (duplicate) and P5 for either assays. The pore water extracted from P3 was only enough for the acute assay (Daphnia similis). The minimum volume necessary for each assay was $300 \mathrm{~mL}$ (acute) and $500 \mathrm{~mL}$ (chronic).

None of the samples presented acute toxicity $($ EC50 > 100\%). All samples presented chronic toxicity,

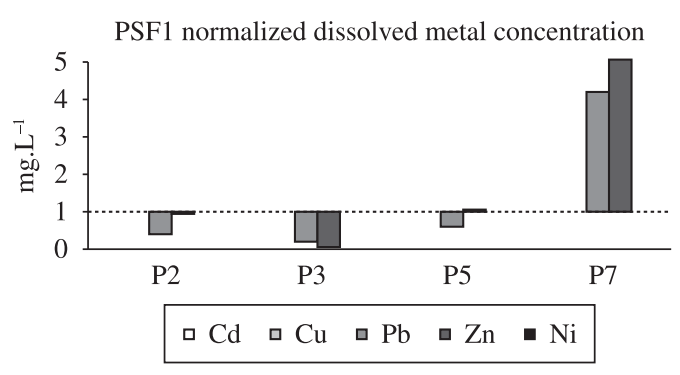

Figure 4. Concentration of dissolved metals in elutriate.

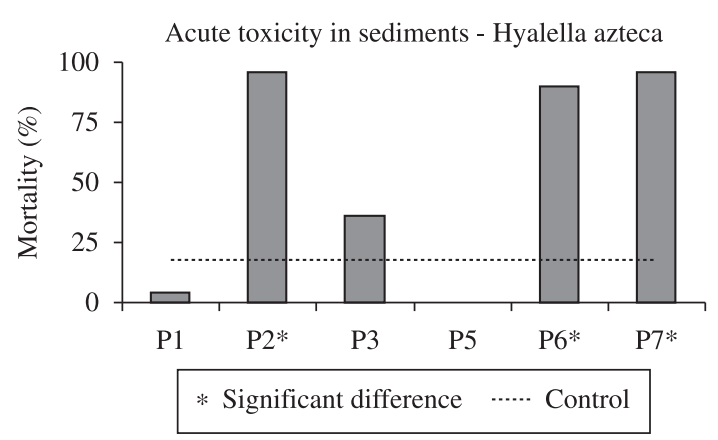

Figure 5. Acute toxicity (mortality) in sediments for the amphipod Hyalella azteca.

Acute (Daphnia similis) e Chronic (Ceridaphnia dubia) Toxicity in interstitial water

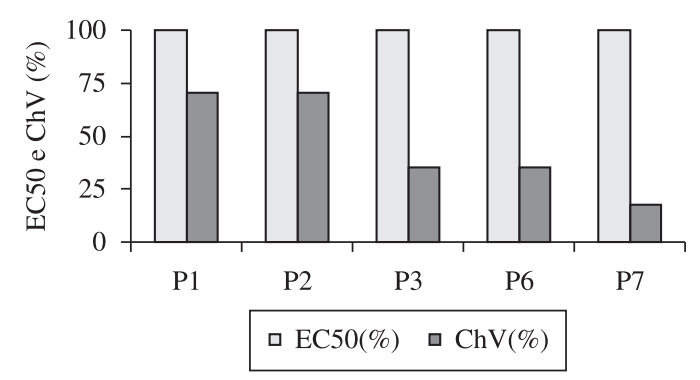

Figure 6. Acute toxicity (immobility) and chronic (reproduction) of pore water of the organisms Daphnia similis and Ceriodaphnia dubia, respectively. including reference sample (P1). Chronic toxicity results for sample P2 was very similar to P1 (70.71\%). P3, P7 and P6 presented higher toxicity (35.36 and $17.68 \%$ ).

The ecotoxicity assays with sediments and non-treated pore water demonstrate that samples of Consciência creek are likely to cause adverse effects to biology. From the three assays, P7 and P6 presented toxicity in two (acute assay with sediments and chronic assay with pore water). São Francisco river samples in front of the tailing dump. It should be mentioned that effluent discharge needs to be studied more. P2 presented acute toxicity in the sediments, but the chronic assay was similar to the reference sample. P3 presented chronic toxicity higher than the reference, but no toxicity in sediments. As no duplicates were tested, the uncertainty remains. The cause of chronic toxicity in the reference sample also needs to studied further, which was not the objective of this work.

\subsubsection{Ecotoxicity of handled pore water}

Results of chronic toxicity assays with pore water handled using N2 and EDTA are presented in Figure 7, as well as the results with non-treated water, for comparison. Manipulated pore water was not tested for acute toxicity because no toxicity was verified in non-treated samples. As mentioned, P2 (duplicate), P3 and P5 were not tested as there was no sufficient extracted water.

Samples P2 and P3, in the São Francisco river did not decrease toxicity after handling. In fact, on the contrary, in some cases the toxicity even increased, which was not expected. The reason for the increase is not clear. The procedures to identify causes of toxicity are complex. Handling with $\mathrm{pH}$ that aims to reduce toxicity of a set of contaminants may increase the toxicity of others. Adding EDTA may cause acidification of the water sample and therefore increase toxicity of sulfide gas (Mozeto et al., 2006).

Samples P7 and P6, in Consciência creek, presented a clear decrease in toxicity when handled. However, the cause of toxicity was not clear as both handling procedures ended in eliminating toxicity. The EDTA addition metal complexion indicates the contribution of such to toxicity.

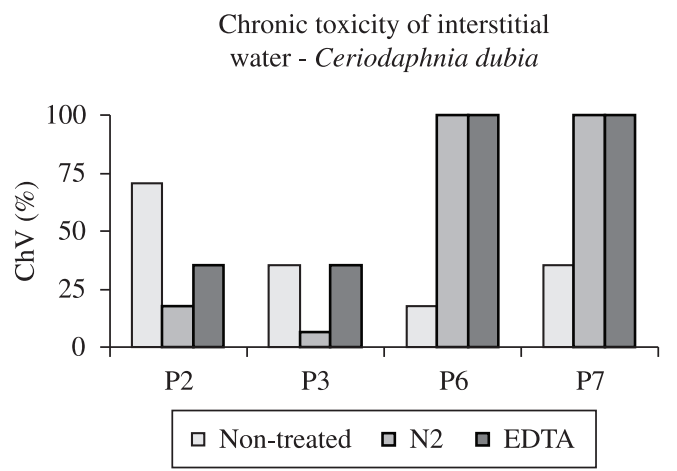

Figure 7. Chronic toxicity (reproduction) of non-treated and handled (with nitrogen and EDTA) pore water samples of the organism Ceriodaphnia dubia. 
Aeration with nitrogen aimed at eliminating sulfide gas and the indication of sulfide contribution to the samples toxicity. Therefore, the cause of toxicity in Consciência samples could either be metals or sulfides. However, during $\mathrm{pH}$ adjustment previous to aeration, metal hydroxyl precipitation was visualized, which was not the objective and could have modified the toxicity for other reasons than sulfide elimination.

Additional tests should be conducted for toxicity identification in the São Francisco river sediments. However, it could be preliminary inferred that the cause of toxicity in those sediments is possibly associated to sulfides and sulfide gas generation, while the cause of toxicity in the Consciência samples may be associated to metals. However, this is very preliminary.

\subsection{Benthic community}

The BMWP scores are presented in Figure 8 as well as the quality classification.

Reference sample (P1) resulted in regular/ bad quality. Samples P2, P4 and P5 presented similar or worse quality (i.e. bad) according to the proposed methodology, although abundance was different from P1. Samples P3, P7 and P6 presented very low BMWP scores, therefore the quality was considered very bad according to the proposed methodology. Once more, P5 proved similar to P1 concerning biological characteristics, contradicting the chemical analysis.

Although this is regional methodology, it did not seem to be the most suitable for the studied site as the reference sample (PSF1) is not contaminated, neither toxic, but the benthic community structure seemed debilitated according to Junqueira et al. (2000). The reason could be that the hydrology profile of the São Francisco river might be such that benthic organism fixation is difficult, giving the impression that the environmental quality is bad. Deposited sediments are often eroded by strong flows (Golder, 2008) mainly caused by a Hydroeletric Generation Power Plant located right before it. The same interpretation does not apply to Consciência creek.

\subsection{Decision matrix/ Weight of evidence}

To fulfill the weight-of-evidence, all results were analyzed according to their probable effect of aquatic

\section{BMWP}

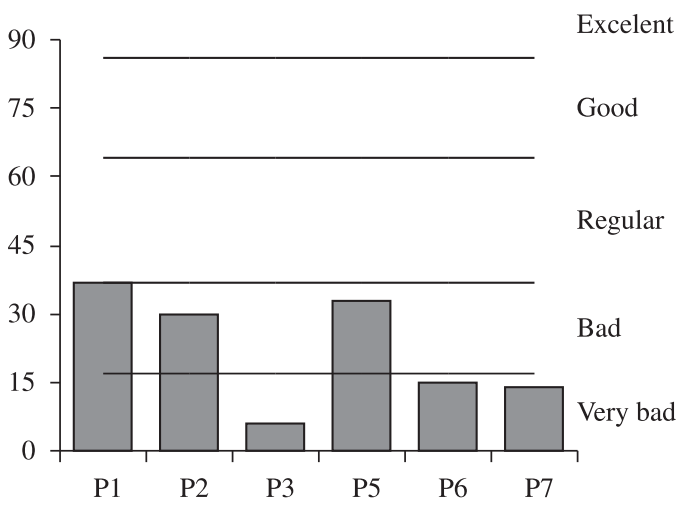

Figure 8. BMWP scores and respective quality. biota, following the criteria described in Table 1, and weighed according to their relevance (Biology is more important than Chemistry). All the results were included in a decision matrix as shown in Table 6 .

The reference sample presented a low BMWP score, probably because of the local hydrological conditions. No contamination was observed, neither acute toxicity. However, chronic toxicity in pore water was observed, which should be studied further. Perhaps the organism used in assays was not the most adequate. Therefore, these two LOEs (BMWP score and chronic toxicity) should be analyzed carefully when assessing other samples. The stability test from elutriate experiments demonstrated a potential of lead and zinc to solubilize in the reference sample (dissolved $\mathrm{Zn}$ and $\mathrm{Pb}$ concentrations in elutriate were above legislation parameters referring to total concentration) (CONAMA, 2005), but this is not a concern since it is a conservative test and does not necessarily mean adverse effect to biota.

The sediments represented by samples P2, P3 and P4 need more research, because the results obtained so far are not sufficient to come to any conclusions. Sample P2 (in front of the tailings dump) presented toxicity of sediments. It is recommended that researchers understand the cause of toxicity and maybe test other native organisms. On the other hand, the BMWP score was similar to the reference sample (P1), although abundance was very different (384 organisms in P1 and 68 organisms in P2). Maybe this is not an adequate measure of a contamination effect to the benthic community and should be adapted to the local conditions. Sample P3 (after effluent discharge) presented moderate contamination and toxicological characteristics similar to the reference sample (P1). However, the BMWP score was much lower than the reference, as well as organism abundance (28 organisms and BMWP score 6). This could be a consequence of discharge itself, which may cause sediment erosion and make organism fixation difficult. The results clearly indicate that benthic community debility is not a consequence of contamination. The toxity of sample P4 (after Consciência creek) was not properly studied.

The region represented by sample P5 (after Retiro Velho creek, after the metallurgy plant) is very similar to the reference sample (P1) and unlikely to represent a risk to biota. Although contamination and bioavailability were observed, this region presents biology characteristics very similar to the reference sample. In this case, geochemical results were assumed incorrect. However, continued monitoring is recommended to ensure risk remains unlikely.

Consciência creek sediments (represented by samples P6 and P7) are more likely to cause risk to biota and this risk is probably associated to metal contamination. Therefore, remedial action and a risk management program should be adopted.

It is worth emphasizing that LOEs were analyzed from unique samplings, therefore they must be refined to diminish uncertainties. The weight of evidence as presented in Table 6 could be redone periodically with new results. 
Almeida, DF., Martins, AH. and Tundisi, JG.

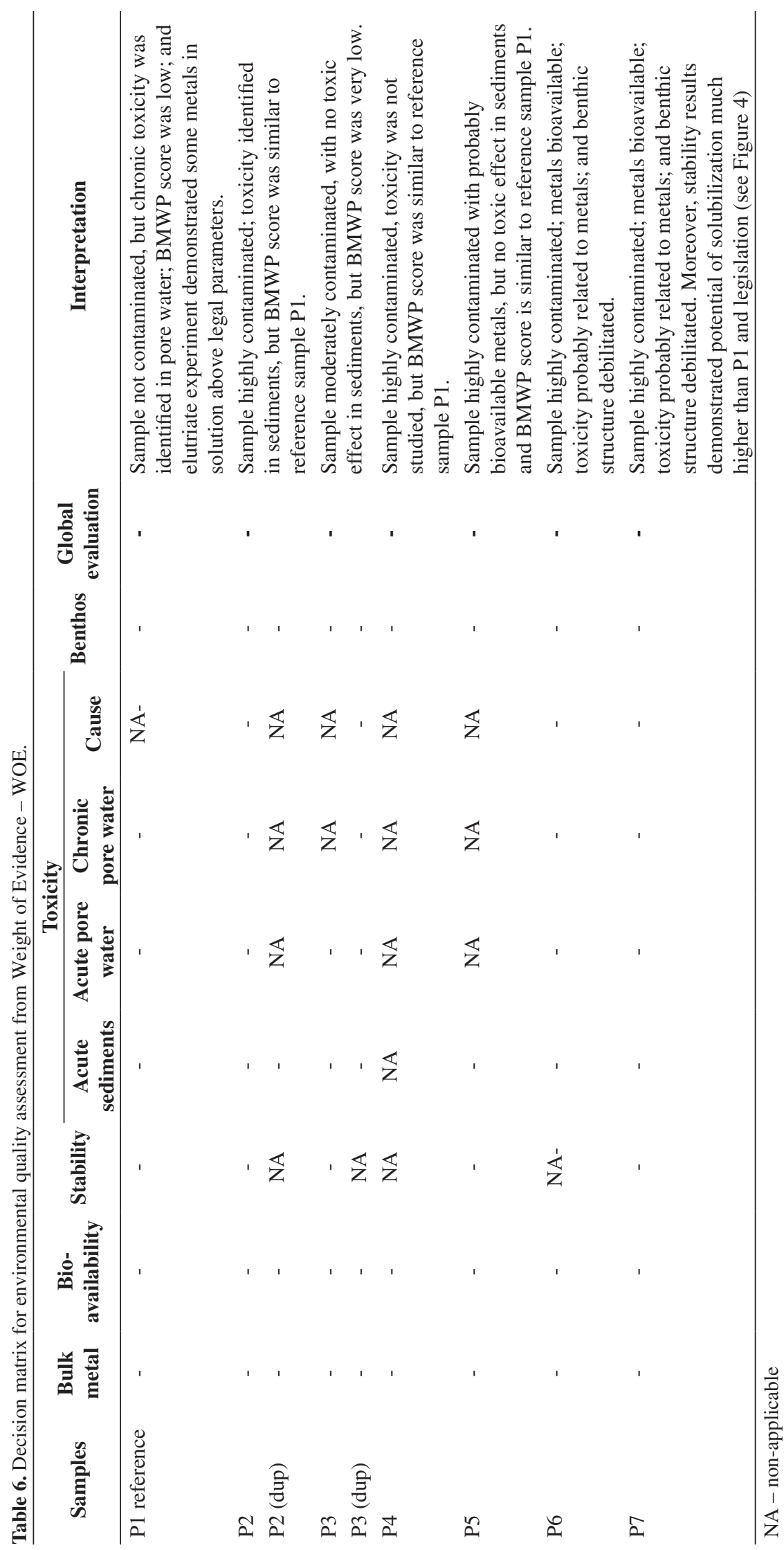




\section{Discussions}

An isolate analysis of bulk metal concentration analysis may lead to the preliminary conclusion that most of the sediment samples presented metal concentrations above the threshold in which adverse biological effects are probably observed, more frequently for the metals zinc ( $\mathrm{Zn})$ and cadmium (Cd), except for samples P1 and P3. However, these results must be jointly analyzed with information on bioavailability and toxicity to support a more realistic conclusion.

When analyzing potential bioavailability, represented by SEM-AVS results, the adverse biological effects are not as certain as bulk metal concentration results suggested. According to the SEM-AVS assays, most samples present part of metal concentrations in the sulfide form, which is unavailable for biota. Therefore, toxicity in most samples is not certain, according to guidelines proposed by Ditoro et al. (1990, 1991, 2000), except for samples P7, P6 and P5. Other important information related to geochemical behavior of sediments was provided by elutriate tests. Results showed that metal solubility in most samples is similar to reference sample (P1), except for P6. Since solubility is closely related to bioavailability, elutriate assay results suggest that sediments are not likely to cause risk to biota.

The chemical and geochemical studies are, however, insufficient to conclude the environmental impact of metals presented in sediments or to support any decision of remediation action. Therefore, other studies focusing on direct effects to biota (ecotoxicity and benthic structure) were developed to provide additional information and support any management decision based on the weightof-evidence approach. Moreover, studies conducted in situ are more realistic than laboratory assays and the weightof-evidence approach reflects this.

Studies on biology provided complementary information. Sample P5 presented contamination (bulk metal concentration) and SEM-AVS indicated probable risks to biota. However, toxicity was not observed during laboratory assays. Moreover, the BMWP was very similar to the reference sample (P1), proving that an overall analysis of different lines-of-evidence in a weight of evidence approach is very important and may lead to more consistent conclusions. On the other hand, pollution caused by Consciência creek sediments was confirmed and therefore, a remedial action and risk management program should be studied.

Concerning remedial actions, classic approaches include: institutional controls, in situ capping, in situ treatment, dredging, excavation or monitored natural recovery. Hybrid approaches can be adopted. All remediation technologies have advantages and disadvantages when applied at a particular site. Before making any decision, a risk management should be developed, short and long terms impacts versus benefits should be analyzed and it is important to consider overall risks, as well as specific risks.

Since samples from São Francisco sediments presented metal sulfides, proving that acid volatile sulfide formation mechanisms are present in the river, which can attenuate metal toxicity eventually identified, the removal of active sources of contamination (for example, from tailings dump) could be sufficient to diminish observed risks to biota. Monitoring Natural Recovery can be applied in this case, not only because of the identified natural attenuating mechanisms, but also because the metals identified are not known to cause biomagnification. The only known metals to biomagnify in aquatic organism are methylmercury and possibly selenium (PARAMETRIX, 1995 apud ICMM, 2007). Continued monitoring is suggested to ensure environmental conditions either improve or remain stable where no risk was observed.

Similar studies based on the weight-of-evidence approach have been developed worldwide, supporting the decision of not dredging sediments contaminated by metals, such as in St. Lawrence river (Great Lakes/Canada) (Grapentine et al., 2002). Other publications include Chapman and Anderson (2005), Chapman et al. (2002), Chapman (2007), McPherson et al. (2008).

\section{Conclusions}

The weight of evidence - WOE is a worldwide used approach and, as expected, was suitable to assess the environmental quality of bed sediments of the São Francisco watershed, based on a risk management decision which was made. The lines of evidences - LOE - did not provide conclusive information to support such a management decision. The criteria used to evaluate the lines-of-evidence, based on legislation and other available literature may be used to assess other contaminated sites.

Acknowledgments - This paper is a contribution to MCT-CNPqINCT-Acqua: Mining, Water resources, Biodiversity.

\section{References}

ALBA-TERCEDOR, J. and SANCHEZ-ORTEGA, A., 1988. Un método rápido y simple para evaluar la calidad biológica de las aguas corrientes basado en el de Helawell (1978). Limnética, vol. 4, p. 51-56.

ALMEIDA, CA., 2007. Aspectos do ciclo de vida de espécies bentônicas nativas e sua utilização na avaliação da qualidade de sedimentos de lagos naturais e reservatórios. São Carlos: Universidade Federal de São Carlos. Tese de Doutorado em Ciências da Engenharia Ambiental.

ALMEIDA, DF., 2010. Gestão Ambiental dos Sedimentos de Corrente do Rio São Francisco na Região de Três Marias (MG/ Brasil). Belo Horizonte: Universidade Federal de Minas Gerais. 94 p. Tese de Doutorado em Engenharia Metalúrgica e de Minas.

American Public Health Association - APHA, 2005. Standard Methods for the Examination of Water and Wastewater $S M E W W$. 20nd Ed. Washington: APHA.

Associação Brasileira de Normas Técnicas - ABNT

, 2004. NBR 12.713: Ecotoxicologia aquática - Toxicidade aguda - Ensaio de toxicidade aguda com Daphnia ssp (Cladocera, Crustacea). Rio de Janeiro: ABNT. 
-, 2005. NBR 13.373: Ecotoxicologia aquática - Toxicidade crônica - Método de ensaio com Ceriodaphnia spp (Crustacea, Cladocera). Rio de Janeiro: ABNT.

-, 2007a. NBR 15.470: Ecotoxicologia aquática - Toxicidade em sedimento - Método de ensaio com Hyalella spp (Amphipoda). Rio de Janeiro: ABNT.

-, 2007b. NBR 15.469: Ecotoxicologia aquática - Preservação e preparo de amostras. Rio de Janeiro: ABNT.

CASTRO, SV., 2006. Efeitos de Metais Pesados Presentes na Água sobre a Estrutura das Comunidades Bentônicas do Alto Rio das Velhas - MG. Belo Horizonte: Universidade Federal de Minas Gerais. Dissertação de Mestrado em Saneamento, Meio Ambiente e Recursos Hídricos.

Canadian Council of Ministers of the Environment - CCME, 1999. Canadian Sediments Quality Guidelines for the Protection of Aquatic Life: Summary tables update 2002. Canadian Environmental Quality Guidelines.

CHAPMAN, PM., 2007.Determining when contamination is pollution - Weight of Evidence determinations for sediments and effluents. Environment International, no. 33, p. 492-501. PMid:17027966.

CHAPMAN, PM. and ANDERSON, J., 2005. A DecisionMaking Framework for Sediment Contamination. Integrated Environmental Assessment and Management, vol. 1, no. 3, p. 163173. PMid:16639882. http://dx.doi.org/10.1897/2005-013R.1

CHAPMAN, PM., MCDONALD, BG. and LAWRENCE, GS., 2002. Weight of Evidence frameworks for sediment quality and other assessment. Human and Ecological Risk Assessment, vol. 8, p. 1489-1515. http://dx.doi.org/10.1080/20028091057457

CHAPMAN, PM. and WANG, F., 1999.Biological Implications of Sulfide in Sediment - A review focusing on sediment toxicity. Environmental Toxicity and Chemistry, vol. 18, no. 11, p. 2526-2532.

CHAPMAN, PM., WANG, F., GERMANO, JD. and BATLEY, G., 2002. Pore water testing and analysis: the good, the bad, and the ugly. Marine Pollution Bulletin, vol. 44, p. 359-366. http:// dx.doi.org/10.1016/S0025-326X(01)00243-0

Conselho Nacional do Meio Ambiente - CONAMA, 2004. Resolução n ${ }^{\circ} 344$, de 25 de março de 2004. Estabelece diretrizes gerais e procedimentos mínimos para avaliação do material a ser dragado de áreas brasileiras. Diário Oficial da República Federativa do Brasil. Brasília, DF, 07 maio. 2004.

-, 2005. Resolução n 357, de 17 de março de 2005. Dispõe sobre a classificação dos corpos de água e diretrizes ambientais para o seu enquadramento, bem como estabelece as condições e padrões de lançamento de efluentes, e dá outras providências. Diário Oficial da República Federativa do Brasil. Brasília, DF, 18 mar. 2005.

DI TORO, DM., HANSEN, DJ., MCGRATH, JM. and BERRY, WJ., 2000. Predicting the toxicity of metals in sediments using SEM and AVS. Draft in preparation.

DI TORO, DM., MAHONEY, JD., HANSEN, DJ. , SCOUT, KJ., HICKS, MB., MAYR, SM. and REDMOND, MS., 1990. Toxicity of Cadmium in Sediments: The role of Acid Volatile Sulphide. Environment Toxicology Chemistry, vol. 9, p. 1487-1502.

DITORO, DM., ZARBA, CS., HANSEN, DJ., BERRY, WJ., SWARTZ, RC., COWAN, CE., PAVLOU, SP., ALLEN, HE., THOMAS, NA. and PAQUIN, PR., 1991. Technical basis for establishing sediment quality criteria for nonionic organic chemicals usong equilibrium partioning. Environment Toxicology Chamistry, vol. 10, p. 1541-1583. http://dx.doi.org/10.1002/etc.5620091208

Golder Associates Brasil - GOLDER, 2006. Zoneamento da distribuição da contaminação de sedimentos do leito submerso do Rio São Francisco - Campanha prévia. Belo Horizonte: GOLDER. Relatório interno.

Golder Associates Brasil - GOLDER, 2008. Zoneamento da distribuição da contaminação de sedimentos do leito submerso do rio São Francisco (RT-079-515-6014-0002-01-J). Belo Horizonte: GOLDER. Relatório interno.

Grapentine, L., Anderson, J., Boyd, D., Burton JUNIOR, GA., DeBarros, C., Johnson, G., Marvin, C., Milani, D., Painter, S., Pascoe, T., Reynoldson, T., Richman, L., Solomon, K. and Chapman, PM., 2002. A decision-making framework for sediment assessment developed for the Great Lakes. Human and Ecological Risk Assessment, vol. 8, p. 1641-1655. http://dx.doi. org/10.1080/20028091057538

GULLEY, DD., BOELTER, AM. and BERGMAN, HL., 1991. TOXSTAT 3.3. Laramie: University of Wyoming. EUA

HAMILTON, M., RUSSO, RC. and THURSTON, RV., 1977. Trimmed Spearman-Karber method for estimating median lethal concentrations in toxicity biossays. Environmental Science \& Technology, vol. 11, no. 7, p. 714-719. http://dx.doi.org/10.1021/ es60130a004

Instituto Internacional de Ecologia e Gerenciamento Ambiental - IIEGA, 2006. Análise dos metais, pesticidas e herbicidas de água superficial e do sedimento e ensaio ecotoxicológico com Daphnia similis e Ceriodaphnia dubia, nos pontos determinados pela FEAM. São Carlos: IIEGA

Instituto Internacional de Ecologia e Gerenciamento Ambiental - IIEGA, 2007. Condições Limnológicas e dos Contaminantes no Médio Rio São Francisco e Afluentes (Avaliação no Ciclo de um ano 2005-2006). São Carlos: IIEGA.

International Council of Mining and Metals - ICMM, 2007. Metals Environmental Risk Assessment Guidance - MERAG. Londres: ICMM.

JUNQUEIRA, MV., AMARANTE, MC., DIAS, CFS. and FRANÇA, ES., 2000. Biomonitoramento da qualidade das águas da Bacia do Alto Rio das Velhas (MG/ Brasil) através de macroinvertebrados. Acta Limnológica Brasileira, vol. 12, p. 73-87.

LUNDHAMER, S., 1991. Erfassung der Kontamination an Metallen im Flusswasser des São Francisco bei Três Marias, Brasilien. Fachhochschule München. 74 p. Doctorate thesis.

MCPHERSON, C., CHAPMAN, PM., DEBRUYN, AMH. and COOPER, L., 2008. The importance of benthos in weight of evidence sediments assessment - A case study. Science of the Total Environment, no. 394, p. 252-264.

MOZETO, AA., NASCIMENTO, MRL., SILVA, EFA. and FIORAVANTI, MIA., 2005. Avaliação da Contaminação por Metais e Metalóide (Água, Sedimento e Peixe) no Rio São Francisco em Três Marias (MG-Brasil). São Carlos: Departamento de Química da UFSCar. Projeto de Pesquisa Participativa com a Comunidade Local.

-, 2007. Avaliação da Contaminação por Metais e Metalóide (Água, Sedimento e Peixe) no Rio São Francisco em Três Marias (MG-Brasil). São Carlos: Departamento de Química da UFSCar. Projeto de Pesquisa Participativa com a Comunidade Local. 
MOZETO, AA., UMBUZEIRO, GA. and JARDIM, WF., 2006. Métodos de Coleta, análises físico-químicas e ensaios biológicos e ecotoxicológicos de sedimentos de água doce. São Carlos. 222 p.

OLIVEIRA, MR., 2007. Investigação da Contaminação por Metais Pesados da Água e do Sedimento de Corrente nas margens do Rio São Francisco e tributários, a jusante da Represa da Cemig, no município de Três Marias, Minas Gerais. Belo Horizonte: Universidade Federal de Minas Gerais. Tese de Doutorado em Geologia.

PLUMB, RH., 1981. Procedures for Handling and Chemical Analysis of Sediment and Water Samples. U.S. Army Corps of Engineers Waterways Experiment Station Environmental Laboratory. 478 p. Technical Report USEPA/CE-81-1.

ROLDAN, G., 2003. Bioindicación de la calidad del agua en Colômbia - Uso del método BMWP. Medellín: Universidad de Antioquia.

SARAIVA, KV., 2007. Critérios para Avaliação da Qualidade de Sedimentos - Estudo de Caso: Sub-bacia do Ribeirão Espírito Santo, Afluente do Rio São Francisco. Belo Horizonte: Universidade Federal de Minas Gerais. Dissertação de Mestrado em Ciência e Tecnologia das Radiações Minerais e Materiais.

United States Environmental Protection Agency - EPA, 2005. EPA-600-R-02-011: Procedures for the Derivation of Equilibrium
Partioning Sediments Benchmarking for the Protection of Benthic Organisms: Metal Mixtures (Cd, $\mathrm{Cu}, \mathrm{Pb}, \mathrm{Ni}, \mathrm{Ag}, \mathrm{Zn}$ ). Washington: Office of Research and Development.

United States Environmental Protection Agency - EPA, 1996a. Method 3050 B: Acid digestion of sediments, sludges, and soils. Washington: EPA.

United States Environmental Protection Agency - EPA, 1996b. Marine Toxicity Identification evaluation (TIE) procedures manual: Phase I guidance document, EPA/600/R-96/054. Washington: EPA.

United States Environmental Protection Agency - EPA, 1995. EPA 823-B-95-001. QA/QC Guidance for Sampling and Analysis of Sediments, Water, and Tissues for Dredged Material Evaluations. Washington: EPA.

United States Environmental Protection Agency - EPA, 1991. Draft Analytical Method for Determination of Acid Volatile Sulfide in Sediment, EPA 821/R-91-100. Washington: EPA.

WANG, F., GOULET, RR. and CHAPMAN, PM., 2004. Testing sediment biological effects with the freshwater amphipod Hyalella azteca: the gap between laboratory and nature. Chemosphere, vol. 57, no. 11, p. 1713-1724. PMid:15519418. http://dx.doi. org/10.1016/j.chemosphere.2004.07.050 
